\author{
Скляр Л.Б. \\ кандидат економічних наук, доцент \\ кафредра обліку та аудиту \\ Одеська національна академія харчових технологій \\ вул. Канатна, 112, м. Одеса, Україна, 65039 \\ E-mail: sklyarl@mail.ru \\ Іванченков В.C. \\ аспірант \\ Інститут проблем ринку та економіко-екологічних досліджень НАН України \\ Французький бульвар, 29, м. Одеса, Україна, 65044 \\ E-mail: I.ivanchenkova@mail.ru
}

\title{
ПРОБЛЕМИ ЗАБЕЗПЕЧЕННЯ ІННОВАЦІЙНОЇ ПРИВАБЛИВОСТІ ПІДПРИЄМСТВ КОНСЕРВНОї ГАЛУЗІ
}

\begin{abstract}
Мета. Метою статті є висвітлення результатів наукових досліджень із забезпечення інноваційної привабливості підприємств консервної галузі. Методика дослідження. Теоретичною і методологічною основою дослідження є фундаментальні положення сучасної економічної теорії, наукові праці вчених, нормативні та законодавчі акти України з питань забезпечення інноваційної діяльності підприємства. В процесі дослідження використовувалися такі методи: методи теоретичного узагальнення - для дослідження теоретичних основ та існуючих концепцій інноваційно-інвестиційної діяльності в консервній галузі; статистичні - при аналізі основних техніко-економічних показників діяльності підприємств консервної промисловості; моделювання і прогнозування - з метою визначення основних напрямів вдосконалення управління потоками економічної інформації в консервній галузі. Результати. Розглянуто окремі техніко-економічні проблеми інноваційного розвитку консервних підприємств. Наведено аналіз основних показників їх фрінансового стану. Визначено основні напрямки покращення інноваційної привабливості підприємств галузі. Наукова новизна. Визначено наступні основні техніко-економічні напрямки покращення інноваційної привабливості підприємств галузі: підвищення технічного рівня виробництва, запровадження ресурсозберігаючих технологій виробництва готової продукції, використання заходів щодо зменшення втрат від сезонності, використання прогресивних форм вирощування сільгоспсировини, широке використання прогресивних форм співпраці з сільгоспвиробниками щодо переробки сільськогосподарської сировини. Практична значущість. Отримані результати дослідження є підґрунтям для вирішення практичних проблем щодо забезпечення інноваційної привабливості підприємств консервної галузі.
\end{abstract}

Ключові слова: підприємства консервної галузі, інноваційний розвиток, продовольча безпека, фрінансовий стан, інноваційна привабливість.

Постановка проблеми та її зв'язок з важливими науковими та практичними завданнями. Важливе значення у підвищенні рівня життя відводиться якості продовольства. Це стосується майже всіх країн світу. Від неякісних продуктів і неправильного харчування гинуть мільйони людей. Якість продукції, забезпечення збалансованого харчування слід розглядати як складову формування державної політики забезпечення продовольчої безпеки країни. При цьому слід зазначити, що підвищення якості харчових продуктів - невід'ємний результат технологічних інновацій підприємств харчової промисловості. Інноваційний розвиток підприємств, який є складовою продовольчої безпеки, тісно пов'язаний із інвестиційною привабливістю вказаних господарюючих структур.

Аналіз останніх публікацій 3 проблеми. Проблеми продовольчої безпеки висвітлюються достатньо широко в роботах вітчизняних науковців Власова В.I. [1], Гойчука О.І. [2], Лозинської Т.М. [3], Лукінова I.I. [4], Саблука П.Т. [5] та інших. Але проблеми інвестиційної привабливості підприємств, які повинні забезпечувати цю продовольчу безпеку, висвітлені недостатньо.

Формулювання цілей дослідження. Основним завданням даного дослідження $є$ розглянути окремі техніко-економічні проблеми інноваційного розвитку консервних підприємств, навести аналіз основних показників їх фінансового стану та визначити основні напрямки покращення інноваційної привабливості підприємств галузі.

Виклад основних результатів та їх обгрунтування. Для забезпечення підвищення якості харчової продукції необхідно забезпечити для галузей вирощування та переробки харчової сировини формування механізму інноваційно-інвестиційного розвитку. Серед підприємств харчової промисловості гідне місце займають підприємства консервної галузі, які в Одеській області є різноманітними за формою власності, розмірами, структурою. Згідно із Статутом вони організовані і діють у відповідності до Законів України «Про підприємства в Україні», «Про власність», Господарського кодексу України та інших законодавчих актів України [6; 7]. До них відносяться: ПРАТ „Виробниче об'єднання „Одеський консервний завод”; ВАТ „Одеський консервний завод дитячого харчування”; СП „Вітмарк-Україна”; ВАТ „Консервний завод „Іллічівський”; ЗАТ „Кодимський консервний завод”; ТОВ „Істок” (м. Білгород-Дністровський). 


\section{ISSN 2312-847X ЕКОНОМІКА ХАРЧОВОЇ ПРОМИСЛОВОСТІ № 1(25) 2015}

Аналізуючи рівень інвестиційної привабливості цих підприємств на етапі формування інвестиційної стратегії, вважаємо за потрібне проаналізувати, перш за все, фінансовий стан підприємства - інноватора, який характеризується як абсолютними, так і відносними показниками, такими як доход від реалізації, прибуток, рентабельність, показники фінансової незалежності, ліквідності балансу та платоспроможності підприємства.

Основні показники результатів діяльності підприємств консервної промисловості Одеської об- ласті свідчать про те, що український ринок плодоовочевої консервації розвивається динамічно (табл. 1). Так, доход від реалізації продукції консервної промисловості Одеської області збільшується щорічно в середньому на 4,0\%.

Це пов'язано з двома факторами. По-перше, відбувається тенденція збільшення рівня доходів та споживчої культури населення. По-друге, молоде покоління українських громадян вже не займається домашніми заготівками, вважає за потрібне купити продукт, що їх цікавить.

Таблиця 1

Доход від реалізації продукції консервної промисловості Одеської області, тис. грн.

\begin{tabular}{|l|c|c|c|c|c|}
\hline \multicolumn{2}{|c|}{ Назва підприємств } & \multicolumn{5}{|c|}{ Роки } & \multicolumn{3}{|c|}{2010} & Темп росту, \% \\
\cline { 2 - 6 } & 2007 & 2008 & 2009 & 135,1 \\
\hline ПРАТ ВО „Одеський консервний завод” & 157629,7 & 203509,0 & 250725,0 & 338702,0 & 85,8 \\
\hline $\begin{array}{l}\text { ВАТ „Одеський консервний завод дитя- } \\
\text { чого харчування” }\end{array}$ & 16064,6 & 30877,3 & 31371,0 & 26912,0 & 105,1 \\
\hline СП „Вітмарк - Україна” & 604551,6 & 726565,1 & 763871,0 & 802828,0 & 69,5 \\
\hline ВАТ „Завод “Іллічівський” & 9068,9 & 110740 & 17721,0 & 12352,0 & 6 \\
\hline ЗАТ „Кодимський консервний завод” & 3354.10 & 3900.00 & 4524.00 & 5248,0 & 116,00 \\
\hline ТОВ „Істок” & 41349,5 & 49429,6 & 54965,7 & 62406,0 & 112,3 \\
\hline
\end{tabular}

Джерело: звітність підприємств

Так, темпи приросту доходу від реалізації ПРАТ ВО „Одеський консервний завод” дорівнюють $35,1 \%$, ВАТ СП „Вітмарк-Україна” - 5,1\%, ТОВ „Істок” - 12,3\%. Доход від реалізації „Одеський консервний завод дитячого харчування" зменшився на $14,2 \%$, ВАТ „Консервний завод “Іллічівський” - на $30,5 \%$.

Прибуток ВАТ „Одеський консервний завод дитячого харчування" дорівнює 52,0\% від стану 2009 p., ТОВ „Істок” - 72,1\%. Так, темпи приросту прибутку ПРАТ ВО „Одеський консервний завод” дорівнюють 155,0\%, СП „Вітмарк-Україна” $108,22 \%$, ВАТ „Консервний завод “Іллічівський” $584,5 \%$. Що стосується ЗАТ „Кодимський консервний завод", то тільки це підприємство працює зі збитком, хоча він у 2010 р. суттєво зменшився.

Незважаючи на додатні результати показників доходності, прибутки підприємств консервної промисловості, що аналізуються, крім СП „ВітмаркУкраїна” та ПРАТ ВО „Одеський консервний завод”, у 2010 р. у порівнянні з 2009 р. суттєво зменшилися (див. табл. 2).

Таблиця 2

Прибуток підприємств консервної промисловості Одеської області, тис. грн.

\begin{tabular}{|l|c|c|c|c|c|}
\hline \multicolumn{1}{|c|}{ Назва підприємств } & \multicolumn{5}{c|}{ Роки } \\
\cline { 2 - 5 } & 2007 & 2008 & 2009 & 2010 & Темп росту,\% \\
\hline $\begin{array}{l}\text { ПРАТ ВО „Одеський консервний за- } \\
\text { вод” }\end{array}$ & 2573,0 & 26817,0 & 9133,0 & 14030,0 & 153,6 \\
\hline $\begin{array}{l}\text { ВАТ „Одеський консервний завод ди- } \\
\text { тячого харчування” }\end{array}$ & 202,5 & 893,0 & 1409,0 & 733,0 & 52,0 \\
\hline СП ТОВ „Вітмарк - Україна” & 144529,0 & 204322,1 & 221126,0 & 239258,0 & 108,2 \\
\hline ВАТ “Завод “Іллічівський” & 270,0 & 0 & $-8710,0$ & $-3805,0$ & 43,7 \\
\hline ЗАТ „Кодимський консервний завод” & $-298,70$ & $-1233,0$ & $-1454,00$ & $-982,0$ & - \\
\hline ТОВ „Істок” & 1124,1 & 1212,9 & 853,0 & 615,0 & 72,10 \\
\hline
\end{tabular}

Джерело: звітність підприємств 
Проаналізуємо рентабельність реалізації підприємств консервної промисловості Одеської області (табл. 3).

Середня рентабельність підприємств консервної промисловості суттєво зменшилася: 3 12,56 \% у 2007 році до 9,42\% у 2010 році.

Найвищою рентабельністю виробництва ха- рактеризуються такі підприємства: СП „ВітмаркУкраїна” (29,80\%); ПРАТ ВО „Одеський консервний завод” (4,14\%); ВАТ „Одеський консервний завод дитячого харчування" $(2,72 \%)$.

Однак $є$ й інші результати роботи. Так, наприклад, рентабельність ВАТ „Завод “Іллічівський” та ЗАТ „Кодимський консервний завод” - від’ємна.

Таблиця 3

Рентабельність реалізації підприсмств консервної промисловості Одеської області, тис. грн.

\begin{tabular}{|l|c|c|c|c|}
\hline \multicolumn{2}{|c|}{ Назва підприємств } & \multicolumn{3}{|c|}{ Роки } \\
\cline { 2 - 5 } & 2007 & 2008 & 2009 & 2010 \\
\hline ПРАТ ВО „Одеський консервний завод” & 17,34 & 13,18 & 3,6 & 4,14 \\
\hline $\begin{array}{l}\text { ВАТ „Одеський консервний завод дитячого харчу- } \\
\text { вання” }\end{array}$ & 11,35 & 20,65 & 18,38 & 2,72 \\
\hline СП „Вітмарк - Україна” ТОВ & 28,40 & 33,15 & 34,12 & 29,80 \\
\hline ВАТ "Завод "Іллічівський" & 8,84 & 8,81 & 9,25 & 10,9 \\
\hline ЗАТ „Кодимський консервний завод” & 12,00 & 9,00 & 10,00 & 11,1 \\
\hline ТОВ „Істок” & 6,25 & 9,22 & 10,68 & 10,00 \\
\hline
\end{tabular}

Джерело: власні розрахунки

Кращі галузеві виробники - ВАТ „Одеський консервний завод дитячого харчування”, СП „Вітмарк - Україна”, ЗАТ ВО „Одеський консервний завод” та низка інших підприємств мають спільну особливість - їх власниками є приватні господарі, заці- кавлені в їх розвитку й ефективній роботі.

Слід відмітити, що собівартість виготовленої продукції підприємств консервної промисловості суттєво коливається (табл. 4).

Таблиця 4

Собівартість виготовленої продукції підприємств консервної промисловості Одеської області, тис. грн.

\begin{tabular}{|l|c|c|c|c|c|}
\hline \multicolumn{1}{|c|}{ Назва підприємств } & \multicolumn{4}{c|}{ Роки } \\
\cline { 2 - 6 } & 2007 & 2008 & 2009 & 2010 & $\begin{array}{c}\text { Tемп росту, } \\
\%\end{array}$ \\
\hline ПРАТ ВО „Одеський консервний завод” & 142034,0 & 149044,0 & 175055,0 & 205689,0 & 117,5 \\
\hline $\begin{array}{l}\text { ВАТ „Одеський консервний завод дитячого } \\
\text { харчування” }\end{array}$ & 11860,1 & 20411,0 & 21333,0 & 18681,0 & 101,5 \\
\hline СП ТОВ „Вітмарк - Україна” & 364439,3 & 411894,2 & 465528,4 & 526047,0 & 113,0 \\
\hline ВАТ “Завод “Іллічівський” & 69094,3 & 100672,6 & 12494,0 & 8187,0 & 65,5 \\
\hline ЗАТ „Кодимський консервний завод” & 2964.80 & 8986.00 & 4092.00 & 2209,7 & 54.46 \\
\hline ТОВ „Істок” & 34124,8 & 40548,1 & 52521,0 & 50083,0 & 95,4 \\
\hline
\end{tabular}

Джерело: звітність підприємств

Структура операційних витрат реалізованої продукції (робіт, послуг) та операційні витрати на одиницю реалізованої продукції за видами промислової діяльності у 2010 р. наведена у табл. 5.

Таблиця 5

Структура операційних витрат реалізованої продукції в 2010 р., \%

\begin{tabular}{|l|c|c|c|c|}
\hline \multicolumn{2}{|c|}{ Назва підприємств } & \multicolumn{3}{|c|}{ Відсотків до загальних витрат } \\
\cline { 2 - 5 } & $\begin{array}{c}\text { мате- } \\
\text { ріальні } \\
\text { витрати }\end{array}$ & $\begin{array}{c}\text { Витрати на } \\
\text { оплату } \\
\text { праці }\end{array}$ & $\begin{array}{c}\text { аморти- } \\
\text { зація }\end{array}$ & $\begin{array}{c}\text { Інші опера- } \\
\text { ційні витрати }\end{array}$ \\
\hline ПРАТ ВО „Одеський консервний завод” & 85,70 & 4,20 & 2,4 & 7,7 \\
\hline $\begin{array}{l}\text { ВАТ „Одеський консервний завод дитячого хар- } \\
\text { чування” }\end{array}$ & 70,00 & 10,5 & 9,0 & 10,5 \\
\hline СП ТОВ „Вітмарк - Україна” & 64,9 & 2,7 & 1,8 & 30,6 \\
\hline ВАТ “Консервний завод “Іллічівський” & 56,0 & 1,3 & 20,5 & 21,5 \\
\hline ЗАТ „Кодимський консервний завод” & 74,0 & 5,8 & 3,8 & 16,4 \\
\hline ТОВ „Істок” & 85,2 & 7,5 & 2,8 & 4,5 \\
\hline
\end{tabular}

Джерело: власні розрахунки 
Так, питома вага матеріальних витрат у структурі операційних витрат харчової промисловості $74,0 \%$ порівняно 3 67,9\% у структурі операційних витрат промисловості взагалі. Витрати на оплату праці в харчової промисловості (5,8\%) менші, ніж у промисловості взагалі $(7,7 \%)$.

Питома вага амортизації як в харчовій промисловості, так і в промисловості взагалі відрізняється на $0,2 \%$.
Плодоовочева консервна промисловість відноситься до галузей 3 високим рівнем матеріаломісткості, що призводить певне навантаження на природне середовище. Питома вага витрат сировини і матеріалів в собівартості іiі продукції складає від 70 до $84 \%$.

Динаміка матеріальних витрат підприємств консервної промисловості наведена у табл. 6.

\section{Матеріальні витрати на виготовлення продукції підприємствами консервної промисловості Одеської} області

\begin{tabular}{|l|c|c|c|c|c|}
\hline \multicolumn{1}{|c|}{ Назва підприємств } & \multicolumn{5}{|c|}{ Роки } \\
\cline { 2 - 6 } & 2007 & 2008 & 2009 & 2010 & Темп росту, \% \\
\hline $\begin{array}{l}\text { ПРАТ ВО „Одеський консервний } \\
\text { завод” }\end{array}$ & 131126,0 & 138824,0 & 145765,0 & 175391,0 & 120,3 \\
\hline $\begin{array}{l}\text { ВАТ „Одеський консервний завод } \\
\text { дитячого харчування” }\end{array}$ & 6690,0 & 13596,0 & 10016,0 & 809,0 & 8,1 \\
\hline $\begin{array}{l}\text { ВАТ “Консервний завод } \\
\text { “Іллічівський” }\end{array}$ & 8346,0 & 3034,0 & 11892,0 & 10119,0 & 85,1 \\
\hline СП ТОВ „Вітмарк -Україна” & 347740,0 & 378306,0 & 375470,0 & 424281,0 & 130,0 \\
\hline ТОВ „Істок” & 29857,0 & 35817,0 & 46095,0 & 43781,0 & 95,0 \\
\hline
\end{tabular}

Джерело: звітність підприємств

Натомість однією з причин низької конкурентоспроможності консервної продукції є високі як прямі виробничі, так і загальновиробничі витрати. Ціни на сировину для консервної промисловості наближаються тут до світових, однак ціни на енергію $є$ значно нижчими. Визначальним фактором залишаються низькі витрати на оплату робочої сили.
Плодоовочеві консервні підприємства належать до промислових підприємств сезонного характеру, тому виробничо-напруженими вважаються літній та осінній періоди. Консервні підприємства, що аналізуються, є досить крупними, про що свідчить рівень середньої вартості основних виробничих засобів у 2009 р. (табл. 7).

Таблиця 7

Рівень середньої вартості основних виробничих засобів підприємств консервної промисловості Одеської області в 2009 р., тис. грн.

\begin{tabular}{|l|c|}
\hline \multicolumn{1}{|c|}{ Назва підприємств } & $\begin{array}{c}\text { Вартість виробничих } \\
\text { фондів }\end{array}$ \\
\hline ПРАТ ВО „Одеський консервний завод” & 35617,0 \\
\hline ВАТ „Одеський консервний завод дитячого харчування” & 39225,0 \\
\hline СП „Вітмарк - Україна” & 71800,9 \\
\hline ВАТ “Консервний завод “Іллічівський” & 23775,0 \\
\hline ЗАТ „Кодимський консервний завод” & 28521,0 \\
\hline ТОВ „Істок” & 15464,0 \\
\hline
\end{tabular}

Джерело: власні розрахунки

Вартість основних засобів перелічених вище підприємств коливається у межах від 15 до 71 млн. грн.
Проаналізуємо рівень зносу основних засобів підприємств консервної промисловості Одеської області (табл. 8). Основні засоби більшості підприємств знаходяться у незадовільному стані. 
Рівень зносу основних засобів підприсмств консервної промисловості Одеської області, \%

\begin{tabular}{|c|c|c|c|c|}
\hline \multirow[t]{2}{*}{ Назва підприємств } & \multicolumn{4}{|c|}{ Роки } \\
\hline & 2007 & 2008 & 2009 & 2010 \\
\hline ПРАТ ВО „Одеський консервний завод” & 20,50 & 40,54 & 51,12 & 52,15 \\
\hline ВАТ „Одеський консервний завод дитячого харчування” & 24,87 & 27,44 & 25,52 & 26,44 \\
\hline СП „Вітмарк - Україна” & 41,15 & 44,10 & 43,29 & 45,37 \\
\hline ВАТ “Консервний завод “Іллічівський” & 68,4 & 60,72 & 32,74 & 35,71 \\
\hline ЗАТ „Кодимський консервний завод” & 27,00 & 25,00 & 31,00 & 35,09 \\
\hline ТОВ „ІІток” & 54,62 & 63,20 & 75,02 & 76,08 \\
\hline
\end{tabular}

Джерело: власні розрахунки

Частка амортизаційних відрахувань в структурі собівартості продукції знаходиться в прямій залежності від ступеню зносу основних засобів та рівня використання виробничих потужностей і не виконує функції джерела інвестування відтворення виробничого апарату.

Як видно з табл. 8, середній знос основних засобів є значним - від 53,2\% у відкритих акціонерних товариствах до майже $51,0 \%$ у закритих. Використання застарілого обладнання, 3 одного боку, гальмує випуск якісної, конкурентоспроможної продукції, а 3 другого - $€$ одним із чинників надмірного навантаження на довкілля. Вартість водозабезпечуючих фондів у загальній вартості основних засобів переробних галузей в середньому становить $25 \%$.

Стан основних виробничих засобів (ОВ3) підприємств консервної промисловості Одеської області поданий у табл. 9.

Таблиця 9

Стан основних засобів підприємств консервної промисловості України

\begin{tabular}{|c|c|c|c|c|}
\hline Показник & \multicolumn{4}{|c|}{ Роки } \\
\cline { 2 - 5 } & 2007 & 2008 & 2009 & 2010 \\
\hline Ступінь зносу основних засобів & 51,1 & 50,4 & 52,3 & 51,2 \\
\hline
\end{tabular}

Джерело: складено на підставі [8]

В умовах глобалізації та подальшої інтеграції у світову економіку, обов'язково необхідно звертати увагу на наявність або відсутність екологічних проблем [9; 10], які тісно пов'язані із технічним станом обладнання та екологічністю технології.

Ці проблеми мають дві сторони:

по-перше, підприємства консервної промисловості утворюють складну екологічну ситуацію, тому що вони, як правило, мають низькі ступені захисту переробки, очистки стічних вод, шкідливих викидів у повітря (харчова промисловість потребує великої кількості тепла для переробки);

по-друге, від консервної промисловості чекають високоякісних екологічно чистих продуктів, для виготовлення яких потрібна екологічно чиста сировина, що $є$ великою проблемою для вітчизняного сільськогосподарського виробництва.

Тож виходить, що підприємства створюють важку екологічну ситуацію викидами шкідливих речовин у повітря, а також забруднена шкідливими речовинами вода попадає на поля та для зрошення i розчинені у ній речовини нагромаджуються у грунті.

Сезонність виробництва - головна особливість діяльності консервних підприємств. Вона проявляється у нерівномірності випуску продукції протягом року, в перервах, піднесеннях і спадах консервного виробництва (табл. 10). 
Таблиця 10

Обсяги виробництва підприємств консервної промисловості Одеської області по кварталах 2010 р.

\begin{tabular}{|l|c|c|c|c|}
\hline \multicolumn{1}{|c|}{ Назва підприємств } & \multicolumn{4}{|c|}{ Квартал 2010 р. } \\
\cline { 2 - 5 } & 1 & 2 & 3 & 4 \\
\hline ПРАТ ВО „Одеський консервний завод” & 37608,0 & 25072,0 & 125360,0 & 62680,0 \\
\hline $\begin{array}{l}\text { ВАТ „Одеський консервний завод дитячого харчу- } \\
\text { вання” }\end{array}$ & 4705,5 & 3137,0 & 15865,0 & 7842,5 \\
\hline СП ТОВ „Вітмарк - Україна” & 114580,5 & 76387,0 & 381935,0 & 190967,5 \\
\hline ВАТ “Консервний завод “Іллічівський” & 22657,5 & 15105,0 & 755250,0 & 377625,0 \\
\hline ЗАТ „Кодимський консервний завод” & 879,0 & 452.00 & 2260,0 & 1130,0 \\
\hline ТОВ „Істок” & 8245,0 & 5496,7 & 27483,5 & 13741,8 \\
\hline
\end{tabular}

Джерело: звітність підприємств

Найбільша питома вага річного випуску продукції підприємств консервної промисловості спостерігається в III кварталі (45-60\%). В IV кварталі спостерігається зниження обсягу виробництва.

Сезонність переробки сировини не дозволяє підприємствам консервної промисловості суттєво збільшувати обсяги виробництва без залучення додаткових потужностей і $є$ основною причиною низької оборотності оборотних коштів в плодоовочеконсервній галузі.

Необхідно пам'ятати, що технологічний процес консервного виробництва тісно пов'язаний з одержанням великої кількості відходів: фруктові вижимки, плодові кісточки, насіння. Питома вага відходів в галузі складає в середньому 25-40\% маси перероблюваної сировини [1]. Відходи містять у собі цінні харчові речовини, а тому можуть використовуватись на даному підприємстві як нова сировина чи напівфабрикати, перероблятись для виготовлення інших харчових і технічних продуктів або реалізовуватись іншим підприємствам. Переробка відходів може частково вирішити проблему сезонності в консервній галузі.

Проведений аналіз дозволив визначити, що до головних техніко-економічних проблем забезпечення інноваційної привабливості підприємств консервної промисловості Одеської області слід віднести наступні:

- значний фізичний і моральний знос основного устаткування;

- низький рівень рентабельності виробництва;

- сезонність виробництва;

- необхідність переробки відходів виробництва;

- необхідність забезпечення екологізації виробництва;
- відсутність цивілізованого ринку сировини, низька якість сировини;

- залежність від врожаю певного виду овочів i фруктів, особливо для вузькоспеціалізованих підприємств.

Виходячи із наведеного вище, визначимо наступні основні техніко-економічні напрямки покращення інноваційної привабливості підприємств галузі:

- підвищення технічного рівня виробництва;

- запровадження ресурсозберігаючих технологій виробництва готової продукції, в т.ч. безвідходних технологій;

- використання заходів щодо зменшення втрат від сезонності;

- використання прогресивних форм вирощування сільгоспсировини;

- широке використання прогресивних форм співпраці 3 сільгоспвиробниками щодо переробки сільськогосподарської сировини.

Висновки та перспективи подальших досліджень. Підвищення рівня продовольчої безпеки держави на основі нарощування виробництва продуктів харчування, поліпшення їх якості та збалансованості за поживними елементами, а також забезпечення більшої доступності кожної людини до продовольчих ресурсів для здорового харчування повинно стати пріоритетом економічного розвитку України. В свою чергу, підтримка відповідного рівня інноваційного розвитку підприємств може стати відповідним гарантом продовольчої безпеки України.

Безумовно, крім забезпечення інноваційної привабливості самого підприємства-інноватора для отримання відповідної інвестиційної підтримки дуже важливим є підтримка інновацій на державному рівні, що обов'язково стане предметом майбутніх досліджень.

\section{Література}

1. Власов В. І. Глобальна продовольча безпека / В. І. Власов. - К. : IAE, 2001. - 506 с.

2. Гойчук О. І. Продовольча безпека : монографія / О. І. Гойчук. - Житомир, Полісся, 2004. - 348 с.

3. Лозинська Т. М. Національний продовольчий ринок в умовах глобалізації : монографія. - Х. : Вид-во ХарРІНАДУ „Магістр”, 2007. - 272 с.

4. Лукінов I. І. Про стратегію трансформування АПК та забезпечення продовольчої безпеки України / I.

І. Лукінов, П. Т. Саблук // Економіка України. - 2000. - № 9. - С. 62-81.

5. Саблук П. Т. Глобалізація і продовольство : монографія / П. Т. Саблук, О. Г. Білоус, В. І. Власов. - К. : HHУ IAE, 2008. - 632 c. 
6. Главинская Л. Т. Корпоративный экологический менеджмент: стратегический аспект (на примере предприятий рыбной промышленности). / Людмила Трофимовна Главинская // Дис. ... Д-ра экон. наук: 08.00.05, Санкт-Петербургский госуниверситет, 2004. - М. : РГБ (фонды Российской гос. библиотеки) - [Электронный pecypc] - Режим доступа : http://diss.rsl.ru/diss/ 06/0321/060321015.pdf

7. Ермолаева В. Е. Ноосфера, экологическая этика и глубинная экология. Гуманитарный экологический журнал. Т. 4. Вып. 2. - 2002. - С. 67-79. $-540 \mathrm{c}$.

8. Статистичний щорічник Одеської області за 2010 рік. - Одеса : Головне управління статистики, 2011.

9. Вареник Н. Экорынок: поможет ли закон накормить дорогой, но сытой продукцией? / Н. Вареник // Зеркало недели. - 31 марта 2012.

10. Купінець Л. Є. Теоретико-методологічні та прикладні засади екологізації продовольчого сектору економіки / Л. С. Купінець. - Автореферат дисертації на здобуття наукового ступеня доктора економічних наук. - Одеса, 2011. - 39 с.

Стаття надійшла 11.02.2015

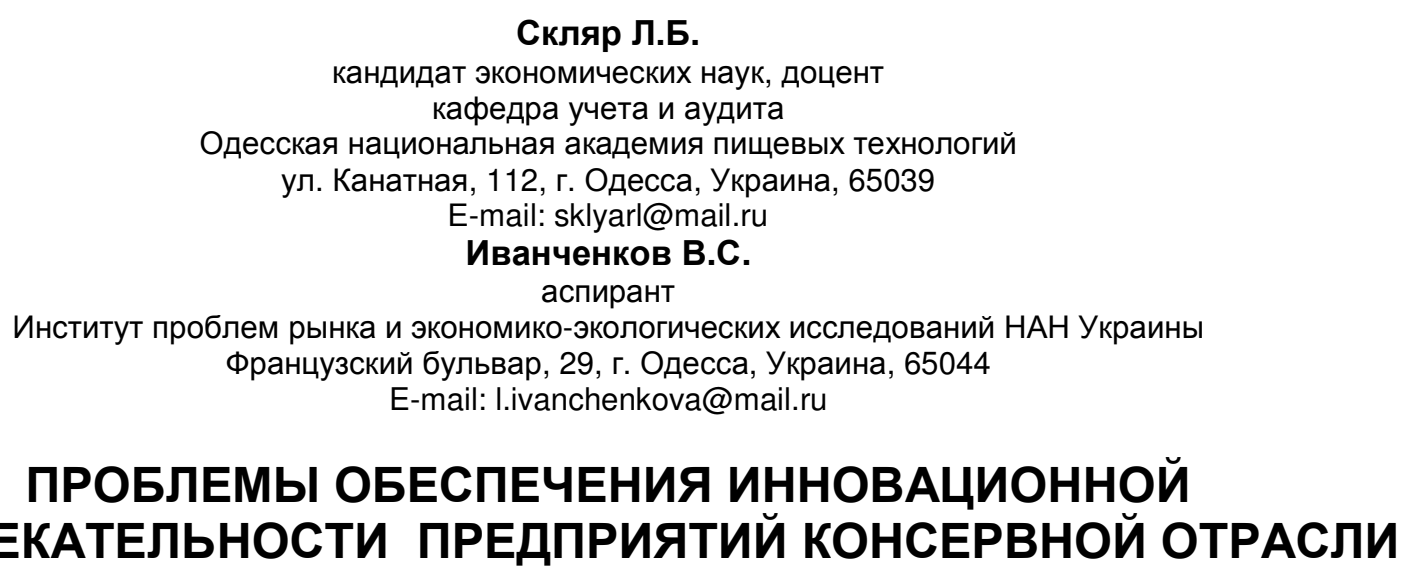

ПРИВЛЕКАТЕЛЬНОСТИ ПРЕДПРИЯТИЙ КОНСЕРВНОЙ ОТРАСЛИ

Цель. Целью статьи является освещение результатов научных исследований по обеспечению инновационной привлекательности предприятий консервной отрасли.

Методика исследования. Теоретической и методологической основой исследования являются фундаментальные положения современной экономической теории, научные труды ученых, нормативные и законодательные акты Украины по вопросам обеспечения инновационной деятельности предприятия. В процессе исследования использовались следующие методы: методы теоретического обобщения - для исследования теоретических основ и существующих концепций инновационно-инвестиционной деятельности в консервной отрасли; статистические - при анализе основных технико-экономических показателей деятельности предприятий консервной промышленности; моделирования и прогнозирования - с целью определения основных направлений совершенствования управления потоками экономической информации в консервной отрасли.

Результаты. Рассмотрены отдельные технико-экономические проблемы инновационного развития консервных предприятий. Приведен анализ основных показателей их фринансового состояния. Определены основные направления улучшения инновационной привлекательности предприятий отрасли.

Научная новизна. Проведенный анализ позволил определить следующие основные техникоэкономические направления улучшения инновационной привлекательности предприятий отрасли: повышение технического уровня производства, внедрение ресурсосберегающих технологий производства готовой продукции, использование мер по уменьшению потерь от сезонности, использование прогрессивных форм выращивания сельхозсырья, широкое использование прогрессивных форм сотрудничества с сельхозпроизводителями по переработке сельскохозяйственного сырья.

Практическая значимость. Полученные результаты исследования являются основой для решения практических проблем по обеспечению инновационной привлекательности предприятий консервной отрасли.

Ключевые слова: инновационное развитие, продовольственная безопасность, финансовое состояние, инновационная привлекательность 


\author{
Sklyar L.B. \\ Ph.D. in Economics, Associate Professor \\ Department of Accounting and Auditing \\ Odessa National Academy of Food Technologies \\ Kanatnaya str., 112, Odessa, Ukraine, 65039 \\ E-mail: sklyarl@mail.ru \\ Ivanchenkov V.S. \\ Postgraduate student \\ Institute of Market Problems and Economic \& Ecological Research \\ of National Academy of Sciences of Ukraine \\ Frantsuzskiy boulevard, 29, Odessa, Ukraine, 65044 \\ E-mail: I.ivanchenkova@mail.ru
}

\title{
THE PROBLEMS OF PROVIDING INNOVATIVE ATTRACTIVENESS OF THE ENTERPRISES OF CANNING INDUSTRY
} industry.

Purpose. The article aims to research papers providing innovative attractiveness of the canning

Research Methodology. The theoretical and methodological basis of research are fundamental tenets of modern economic theory, scientific work of scientists, regulatory and legislative acts of Ukraine for innovation company. The study used the following methods: methods of theoretical generalization - to study the theoretical foundations and current concepts of innovation and investment in the canning industry; statistics - the analysis of the main technical and economic performance indicators canning industry; modeling and forecasting - to determine the main directions of improving the management of the flow of economic information in the canning industry.

Results. Several specific technical and economic problems of innovative development of canning companies. The analysis of the main indicators of their financial situation. The main areas for improvement innovation attractiveness of the industry.

Scientific novelty. The analysis allowed to identify the following main technical and economic trends improve the attractiveness of the industry innovation, improve the technical level of production, the introduction of resource-saving technologies of production of finished products, the use of measures to reduce losses from seasonality, the use of advanced forms of cultivation of agricultural raw, the widespread use of advanced forms of cooperation with farmers on processing of agricultural products.

The practical significance. The results of research is the foundation for solving practical problems concerning the provision of innovative attractiveness of the canning industry.

Keywords: innovative development, food security, financial condition, innovation attractiveness.

\section{References}

1. Vlasov V. I. (2001). Hlobalna prodovolcha bezpeka. V. I. Vlasov. K. : IAE, 506.

2. Hoichuk O. I. (2004). Prodovolcha bezpeka : monohrafiia. O. I. Hoichuk. - Zhytomyr, Polissia, 348.

3. Lozynska T. M. (2007). Natsionalnyi prodovolchyi rynok v umovakh hlobalizatsii : monohrafiia. Kh. : Vydvo KharRINADU „Mahistr”, 272.

4. Lukinov I. I. (2000). Pro stratehiiu transformuvannia APK ta zabezpechennia prodovolchoi bezpeky Ukrainy. I. I. Lukinov, P. T. Sabluk. Ekonomika Ukrainy, № 9, 62-81.

5. Sabluk P. T. (2008). Hlobalizatsiia i prodovolstvo : monohrafiia. P. T. Sabluk, O. H. Bilous, V. I. Vlasov. K. : NNU IAE, 632.

6. Hlavynskaia L. T. (2004). Korporatyvnyi ekolohycheskyi menedzhment: stratehycheskyi aspekt (na prymere predpryiatyi rybnoi promyshlennosty). Liudmyla Trofymovna Hlavynskaia. Dys. ... d-ra ekon. nauk : 08.00.05, Sankt-Peterburhskyi hosunyversytet, M. : RHB (fondy Rossyiskoi hos. byblyoteky). [Elektronnyi resurs] Rezhym dostupa : http://diss.rsl.ru/diss/06/ 0321/060321015.pdf.

7. Ermolaeva V. E. (2002). Noosfera, ecolohycheskaia etyka y hlubynnaia ekolohyia. Humanytarnyi ekolohycheskyi zhurnal. Vol. 4, 2, 67-79. 540.

8. Statystychnyi shchorichnyk Odeskoi oblasti za 2010 rik. (2011). Odesa : Holovne upravlinnia statystyky,

9. Varenyk N. (2012). Ekorynok: pomozhet ly zakon nakormyt dorohoi, no sytoi produktsyei? Zerkalo nedely, 31 marta.

10. Kupinets L. Ye. (2011). Teoretyko-metodolohichni ta prykladni zasady ekolohizatsii prodovolchoho sektoru ekonomiky. Avtoreferat dysertatsii na zdobuttia naukovoho stupenia doktora ekonomichnykh nauk. Odesa, 39. 